\title{
コンクリート構造実験を対象とした リアルタイム画像解析システムの開発
}

\author{
渡辺 健 1 ・東 広憲 $2 \cdot$ 三木朋広 $3 \cdot$ 二羽淳一郎 4 \\ 1正会員 東京工業大学大学院助教 理工学研究科土木工学専攻 ( $\bar{T} 152-8552$ 東京都目黒区大岡山2-12-1) \\ E-mail: ken@cv.titech.ac.jp \\ 2正会員 大成建設株式会社 土木設計部海洋設計室 ( \\ E-mail: hgshrn00@pub.taisei.co.jp \\ 3 正会員 神戸大学大学院准教授 工学研究科市民工学専攻（ 产657-8501 神戸市灘区六甲台町1-1） \\ E-mail: mikitomo@port.kobe-u.ac.jp \\ 4フェロー 東京工業大学大学院教授 理工学研究科土木工学専攻 ( \\ E-mail: jniwa@cr.titech.ac.jp
}

\begin{abstract}
本研究では, 載荷中の試験体の変形を画像解析を用いて計測し, 有限要素の形状関数により算出したひ ずみの分布を示すことで視覚的に試験体の変形を捉えるという一連の作業を，載荷中に行うことができる リアルタイム画像解析システムを開発した。そして, 鉄筋コンクリート (RC) はりの載荷実験を行い, 目 視では判別できない主引張ひずみを，リアルタイム画像解析を利用して可視化することで，載荷が進むに 伴いひずみが集中する部位を評価した。 そして, 曲げ引張型および斜め引張型破壞といった $\mathrm{RC}$ はりの最 終的な破壊形態を，載荷中に予測できることを確認した。
\end{abstract}

Key Words : image analysis, real time, reinforced concrete, strain measurement system, maximum principle strain, failure mechanism

\section{1. はじめに}

曲げ破壊やせん断破壊など，鉄筋コンクリート (RC) 部材の破壊機構を同定することは，RC部材の而何力な ど力学性能を把握するうえで重要である. そのためには, 構造実験において，ひび割れおよび鉄筋の降伏などRC 部材の局所部が示寸力学挙動が，RC部材全体としての 変形および而扵にどのように関連しているのかといった RC部材の破壊過程を，総合的に追跡寸ることが必須で ある， RC部材の載荷実験では，部材の力学状態を推定 する手法として，荷重，ひずみあるいは変位情報に頼つ た議論が多い, しかしながら, 従来の計測手法では, 計 測器具の設置位置および方法に依存した限定的な情報し か得られず， $\mathrm{RC}$ 部材の破壊過程を包括的に説明するた めには，有限要素解析など計算力学的手法により情報を 補完する必要があった.

対象物の広領域を対象に, 物体の特徵量を抽出でき る手法として, 画像処理が挙げられる. 画像処理は, 対 象物を撮影したデジタル画像を構成する各ピクセルの情 報を利用し，対象物の形状，寸法および位置などを把握 する手法である. 対象物に物理的な影響を全く与えずに,
その形状，寸法および位置などを簡便に評価可能な手法 であり， RC 構造物表面に発生しているひび割れ検出な じ，土木分野でも実用化されている ${ }^{1)}$.

画像処理を通して得た情報を，ひずみ量などに変換 して利用寸る画像解析法は, 様々な分野で開発が進めら れている ${ }^{2), 3)}$. 近年では, 電子スペックル干渉法 ${ }^{4)}$, デ ジタル画像相関法 5), 9, 7および格子法 ${ }^{8)}$, 9), 10)などの，コ ンクリート構造実験への導入が報告されている. それぞ れ実験環境および要求精度に応じて利用が区別できるが, 特に数メートルの寸法を有する $\mathrm{RC}$ 部材の載荷実験では, 供試体表面に設置した標点の移動量からひずみを算出す る，格子法が多く利用されている，筆者らは，この格子 法に高次の有限要素を組み込むことで，コンクリートの ひび割れの進展をより現実的に評価できることを確認し ている ${ }^{11)}$ ，画像解析は，計測が試験体表面に限定される が， RC 棒部材の曲げ試験など平面応力場が仮定できる 対象物には，十分な効果が得られる手法であると考えら れる.

ところで，従来の画像解析を利用した計測システム では，載荷中に試験体を撮影した画像を用いて，実験終 了後に画像解析を実施して結果を取得することが一般的 


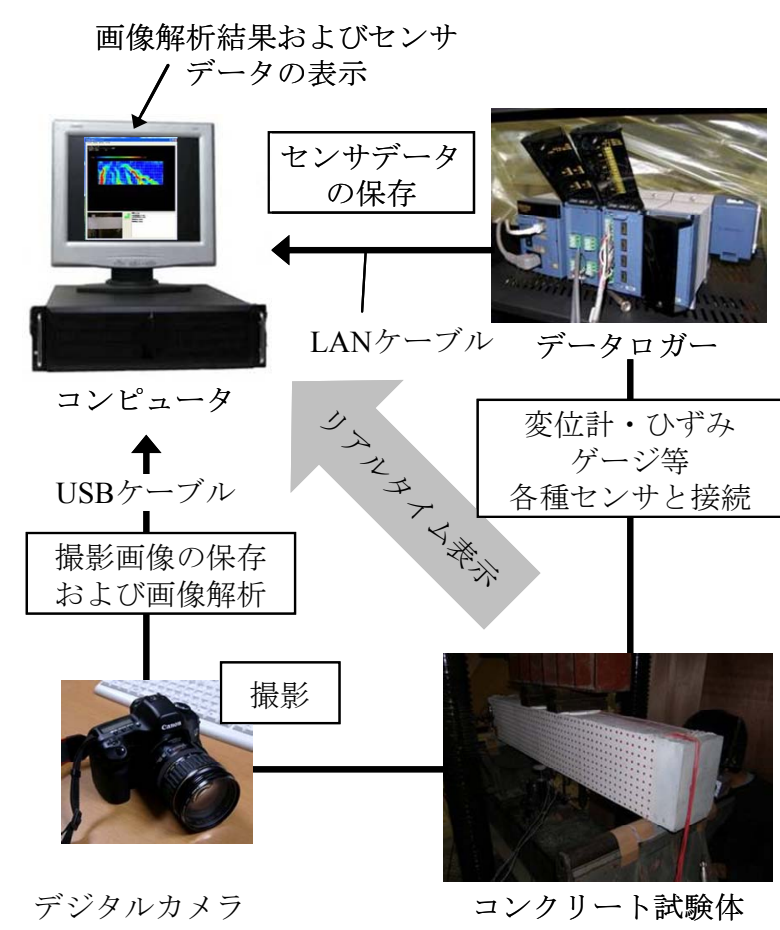

図-1 システムの構成

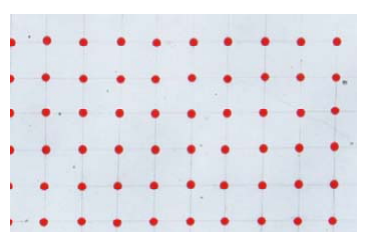

(a) 標点の貼付

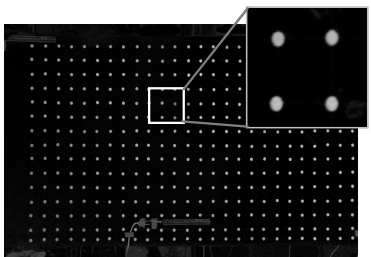

(c) グレースケール化

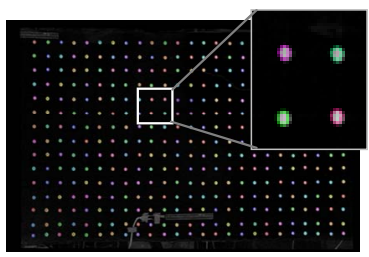

(e)エッジ抽出，円近似お よび重心座標算出

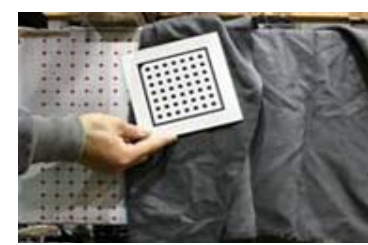

(b) カメラキャリブレー ション

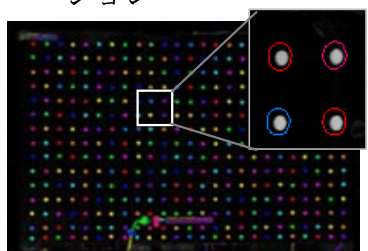

(d) 2值化によるマスク処理 (円内が検查対象領域)

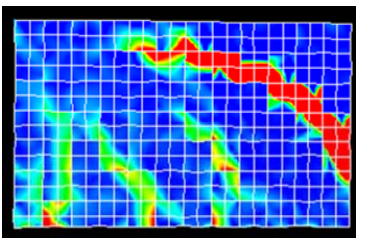

(f) 有限要素によるひずみ の算出およびコンター による可視化

図-2＼cjkstart格子法によるひずみ算出過程
であった。しかしながら， RC 部材全域に生じるひずみ 分布をリアルタイムに算出することが可能になれば，観 察のために載荷を中断することなく載荷中に破壊部位や 形態を特定できる．その結果，実験の信頼性の向上に資 するだけでなく, 載荷中に新たに測定器具を追加するこ とが提案でき， $\mathrm{RC}$ 部材の破壊現象の詳細な追跡が可能 となる。これは，破壊形態があらかじめ予測できない新 しいコンクリート構造実験に対しても， RC 部材の力学 性能の評価に十分貢献できることを意味しており，その 意義は大きい，画像解析時間の短縮については，舘石 ${ }^{12)}$ により既に検討されているが， $\mathrm{RC}$ 部材の破壊部位をリ アルタイムに同定し，載荷中に破壊形態を予測するため には, 精度向上や画像解析の高速化の点でさらに議論を 行う余地があった。

本研究は, RC 部材の破壞実験を対象に，載荷中に $\mathrm{RC}$ 部材表面に発生しているひずみを可視化できる，リ アルタイム画像解析システムを構築することを目的とし ている. すなわち，画像解析を実施して $20 \mathrm{~mm}$ の局所 部で発生した変位から， RC 部材表面に発生するひずみ を算出し，他のセンサを使用して計測した RC 構造部材 としての力学挙動と時間的に関連付けて, 載荷中に表示 するシステムを目指す，検討では， $\mathrm{RC}$ 部材の破壊実験 への使用を念頭において，画像解析時間を短縮寸るため に節点数を減らし，部材の変形および破壊箇所を簡便に 把握できる程度の十分な分解能を有する，格子法を利用 した，そして，画像処理に関わる既往の報告を踏襲して， 計測精度に関わる実験条件を $\mathrm{RC}$ 部材の載荷環境に配慮
して再整理した. 最後に, 構築したリアルタイム画像解 析システムを $\mathrm{RC}$ はりの曲げ試験に適用し，ひずみ分布 を算出することで破壊性状，特にひび割れの発生位置お よび形状の再現性を確認した。 そして，曲げ引張型破壊 および斜め引張型破壊という RC はりの最終破壊形態を 載荷中に予測することに対する，本システムの有用性を 示した.

\section{2. リアルタイム画像解析システムの開発}

\section{（1）リアルタイム画像解析システムの構成}

図-1 に，筆者らが画像解析を利用して構筑したリア ルタイム画像解析システムの構成を示寸，本システムで は，撮影したデジタル画像および画像解析結果と，各種 センサによりデータロガーを通して計測した值を，時間 的に関連付けて記録している. 寸なわち，載荷中，デジ タルカメラのシャッターを押すと, 撮影画像がコンピュ 一夕に転送され，直後に画像解析結果を表示寸る．併せ て，同一時刻に各種センサで計測した荷重や変位を，デ ータロガーを通してコンピュータに保存するシステムで ある. すなわち，画像解析で計測する $\mathrm{RC}$ 部材表面の変 位は，コンクリートと内部に配置した補強鉄筋の挙動を 統合した結果であると考える．さらに各種センサの計測 結果を併せて表示寸ることで，様々な破壊形式にも展開 できるよう配慮したものである. 


\section{(2) 画像処理}

図-2 に，格子法によるひずみ算出過程を示す．なお， 本システムで使用寸る画像の保存には，データ量を縮小 して画像処理速度を高めるために，圧縮率を約 25〜 39\%とした圧縮画像(JPEG形式)を使用した.

\section{a) 標点の貼付}

格子法を利用するために，標点を試験体表面に配置

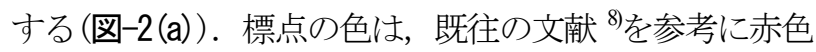
を採用した. なお, 既往の研究では, 高輝度型発光ダイ オード(LED : Light Emitting Diode)を標点として使用した

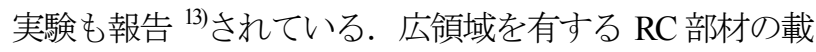
荷実験を対象とした本研究では，多数の標点の配線が煩 雑になることを懸念して，標点として市販の紙製赤色シ 一ルを，載荷中に試験体から剥離しないよう入念に貼付 した.

\section{b) カメラキャリブレーション}

本研究では，複数の球面・非球面レンズで構成され る標準レンズを使用している，そのため，透過した光線 は 1 点に集中せず，収差が発生する ${ }^{14)}$. そこで，載荷前 に，画像の歪み(歪曲収差)を補正するため, ピンホール カメラの原理を応用したカメラキャリブレーションを実 施した. これは, カメラの焦点距離や撮像素子 (CCD : Charge Coupled Devices)の画素の縦横比を示す内部パラメ 一タと, 試験体に対するカメラの位置・向きを表す外部 パラメータを把握する作業である，すなわち，試験体表 面の標点位置と，画像におけるそれらの投影の相対関係 を求めておくことで, 対象物の形状・寸法を画像で復元 するものである ${ }^{15}$.

実験に際し, 市販のプレート(図-2(b))を用意し, 試 験体表面の撮影範囲にて適宜プレートを動かして, 様々 な角度のプレートを撮影した 30 枚以上の画像を基に収 差補正を実施した. 図-3 に，カメラキャリブレーショ ンによる歪曲収差補正を示す. カメラパラメータを決定 することで, 撮影した画像の歪曲収差を適切に補正した 結果, プレートの樽型の歪みが除去できることを確認し た.

\section{c）グレースケール化}

デジタルカメラで撮影したカラー画像は，画像中の 各位置に対し三原色 : 赤 $(\mathrm{R})$, 緑 $(\mathrm{G})$, 青 $(\mathrm{B})$ の, それ ぞれの画素值を有している，本システムでは，処理速度 を向上させるために，撮影画像を RGB 色空間から，色 相 (Hue), 彩度 (Saturation), 明度 (Intensity)で色を表現す る HSI 色空間に変換している. そして, 彩度 (S)のみを 抽出することで, 図-2(c)に示すとおり，標点が際立っ たグレースケール画像を入手することができる. すなわ ち，彩度に基づく明るさ (輝度)の分布に変換することで， 各画素が有する画素值のデータ量は, RGB カラー画像 の約 $1 / 3$ となっている.
図中の赤線は，収差補正後を示す。

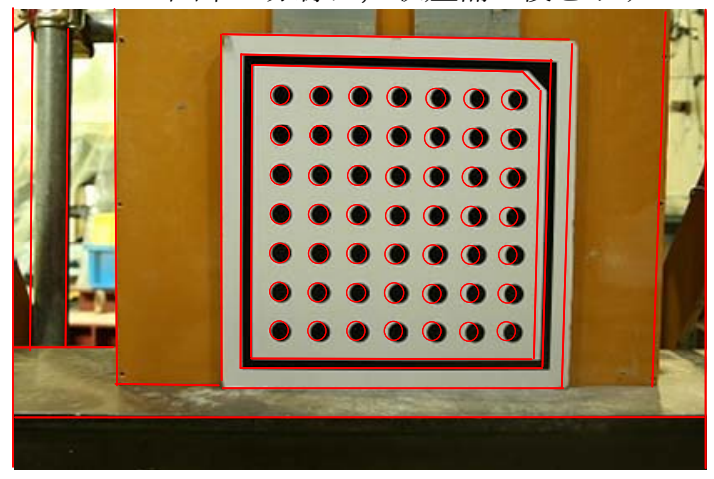

図-3カメラキャリブレーションによる歪曲収差補正

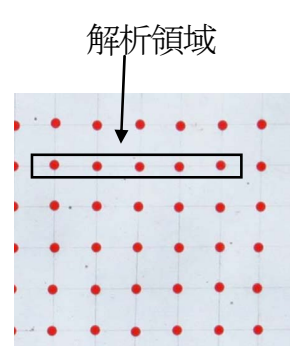

(a) 原画像

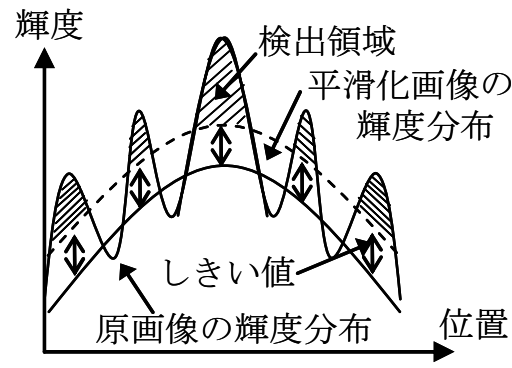

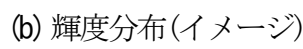

図-4 動的しきい值法の考え方

\section{d） 2 值化を用いたマスク処理}

高速かつ精度よくグレースケール画像から標点を抽 出するために，2 值化を用いたマスク処理 ${ }^{15)}$ を行い, 画像処理を行う検査対象領域を，標点周辺の夕に絞り込 んだ.これは，前処理にて輝度分布として変換された画 像に対して輝度にしきい值を設定し，標点とほぼ同様の 輝度を有する領域を白色として，それ以外の領域(黒色) と区別して抽出する作業である.

ところで，影や載荷中の光環境の変化により輝度レ ベルが変動する画像に対して，固定のしきい值を適用す ることは，適当ではない，そこで，本システムでは，画 像中の位置ごとの輝度に応じて最適なしきい值を設定す る動的しきい值法を採用している ${ }^{15)}$. 図-4 に, 動的し きい值法の概念図を示す．動的しきい值法では，任意の 領域 (本研究では高さ $100 \times 100$ ピクセル)ごとに, 滑ら

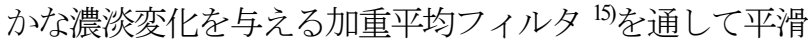
化した画像の輝度分布を用いた。 そして，原画像と平滑 化した画像との輝度值との差分に一定のしきい值(動的 しきい值)を設定して検出領域を決定し，画像を 2 值化 するものである。このしきい值は，試験体に配置したす べての標点の全域を把握できるように，実験ごとに逐一 設定している. この際, 円形である標点の特徵量(幅, 高さ, 面積 $(S)$, 真円度 $\left(=S /\left(M a x^{2} \pi\right)\right.$ ただし, $M a x$ : 領 域の中心から距離の最大值))を利用して標点近辺を抽出 し，その他のノイズを除去する. 図-2(d)に示すとおり， 
すべての標点が検査対象領域に含まれるように, 検出領 域は臨機応変に膨張させている.

\section{e）標点抽出および重心座標の算出}

2 值化画像 (マスク画像)の検查対象領域(白色領域)に 対応するグレースケール画像(図-2(c)) より, 標点の領 域はその他の領域(コンクリート) と比較寸ると, 明るい (輝度が大きい)ことがわかる，つまり，輝度が急激に変 化するエッジを検出した後, 円近似を行うことで標点を 抽出して，その重心座標を算出した(図-2(e)).

本研究では, 標点を縦横に規則的に配置している. 載荷中, 標点の対応付けは, 前段階で求められた標点位 置と比較するテンプレートマッチングにより追跡するこ とで行った.

\section{（3）有限要素によるひずみの算出}

標点の重心座標を節点位置として，9節点アイソパラ メトリック要素で試験体を離散化した有限要素モデルを 構築した. 載荷開始前後の画像を利用して, 標点の重心 座標の変化から標点の移動量 $(u, v)$ を算出寸る. そして, 図-5 に示寸とおり，9節点アイソパラメトリック要素の, 任意点の変位 $(u, v)$ は, 節点変位 $\left(u_{i}, v_{i}\right)$ と形状関数 $\mathrm{N}_{\mathrm{i}}(\xi$, ๆ)を用いて，式(1) (2)のように関係付けられる ${ }^{10}$.

$$
\begin{gathered}
u=\sum_{i} N_{\mathrm{i}}(\xi, \eta) u_{i} \\
v=\sum_{i} N_{\mathrm{i}}(\xi, \eta) v_{i}
\end{gathered}
$$

ここで, $N_{\mathrm{i}}(\xi, \eta): 9$ 節点アイソパラメトリック要素の 節点 $\mathrm{i}$ の形状関数, $(\xi, \eta)$ : 自然座標, $(x, y)$ : 直交座

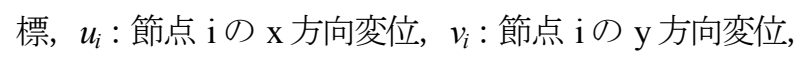
である、また, 要素内のひずみ $(\varepsilon)$, 最大主ひずみ $\left(\varepsilon_{1}\right)$ および最小主ひずみ $\left(\varepsilon_{2}\right)$ は，以下のとおり算出される.

$$
\begin{gathered}
\{\varepsilon\}=\left\{\begin{array}{c}
\varepsilon_{x} \\
\varepsilon_{y} \\
\gamma_{x y}
\end{array}\right\}=\left\{\begin{array}{c}
\partial u / \partial x \\
\partial v / \partial y \\
\partial u / \partial y+\partial v / \partial x
\end{array}\right\} \\
\varepsilon_{1}=\frac{1}{2}\left(\varepsilon_{x}+\varepsilon_{y}\right)+\sqrt{\left(\frac{\varepsilon_{x}-\varepsilon_{y}}{2}\right)^{2}+\left(\frac{\gamma_{x y}}{2}\right)^{2}} \\
\varepsilon_{2}=\frac{1}{2}\left(\varepsilon_{x}+\varepsilon_{y}\right)-\sqrt{\left(\frac{\varepsilon_{x}-\varepsilon_{y}}{2}\right)^{2}+\left(\frac{\gamma_{x y}}{2}\right)^{2}}
\end{gathered}
$$

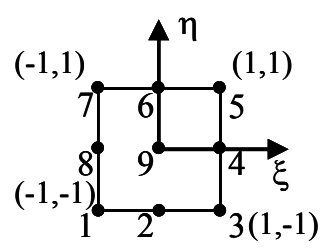

自然座標系

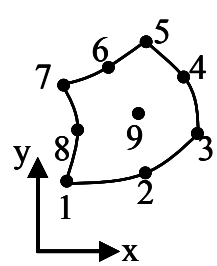

直交座標系

$$
\begin{aligned}
& N_{1}=\frac{1}{4} \xi \eta(1-\xi)(1-\eta) \quad N_{6}=\frac{1}{2} \eta\left(1-\xi^{2}\right)(1+\eta) \\
& N_{2}=-\frac{1}{2} \eta\left(1-\xi^{2}\right)(1-\eta) \quad N_{7}=-\frac{1}{4} \xi \eta(1-\xi)(1+\eta) \\
& N_{3}=-\frac{1}{4} \xi \eta(1+\xi)(1-\eta) \quad N_{8}=-\frac{1}{2} \xi(1-\xi)\left(1-\eta^{2}\right) \\
& N_{4}=\frac{1}{2} \xi(1+\xi)\left(1-\eta^{2}\right) \quad N_{9}=\left(1-\xi^{2}\right)\left(1-\eta^{2}\right) \\
& N_{5}=\frac{1}{4} \xi \eta(1+\xi)(1+\eta) \\
& \text { ここで, } \mathrm{N}_{\mathrm{i}} \text { : 各節点の形状関数, }
\end{aligned}
$$

$\xi, \eta:$ 要素内の正規化座標

図-5 9節点アイソパラメトリック要素 ${ }^{16}$

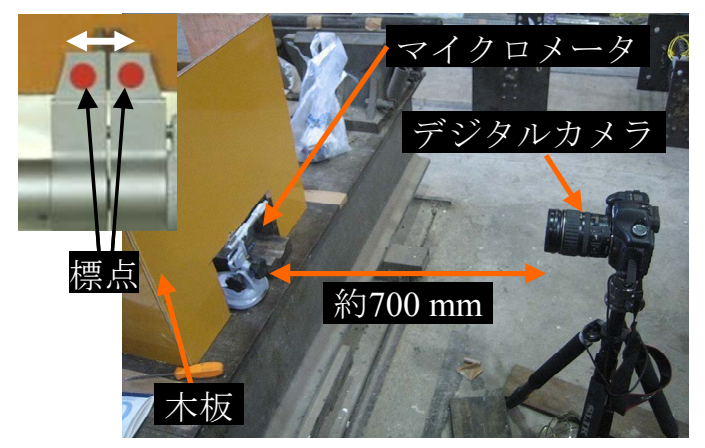

図-6 画像解析に適した載荷実験環境の検証

ここで， $\varepsilon_{x}: \mathrm{x}$ 方向ひずみ， $\varepsilon_{y}: \mathrm{y}$ 方向ひずみ，および $\gamma_{x y}$ : せん断ひずみ, である. 最終的に, 算出した要素内 のひずみ $\left(\varepsilon_{x} ， \varepsilon_{y} ， \gamma_{n}\right)$ ，最大主ひずみ $\left(\varepsilon_{1}\right)$ および最小主ひ ずみ $\left(\varepsilon_{2}\right)$ を、コンター図で表示する(図-2(f)).

骨材，セメントペースト，空隙，補強材およびひび 割れなどで構成されるコンクリート部を連続体として捉 え，要素内のひずみを格子点の変位を補間することで算 出した. このひずみの絶対值は要素寸法に依存して変化 するため, 目的に応じた要素寸法の設定が必要になるが, 部位ごとに異なる变形を可視化するうえで有効である.

\section{（4）まとめ}

以上，格子法を用いた本システムの画像解析の手順 をまとめた. 載荷中にリアルタイムに画像解析を行うた めに, 載荷開始直前にカメラキャリブレーションを実施 して, カメラパラメータおよび動的しきい值をコンピュ 一夕に記憶させる. その後, 載荷実験を開始し, 載荷中 に試験体を撮影寸ると，画像解析に関する一連の作業が 自動的に実行されることになる. 


\section{3. 画像解析に対する載荷実験環境の検証}

\section{（1）レンズの設定}

単焦点レンズを使用すると, 収差の緩和および低い F 值(=レンズの焦点距離/レンズ直径)のため明るい画像が 取得できるなど，画像解析に対して有利な点が多いと考 える.しかし，寸法が異なる $\mathrm{RC}$ 部材の載荷実験ごとに 焦点距離を合わせたレンズを用意することは現実的では ない. したがって，本研究では焦点距離が 17～85 mmに 可変な標準レンズを使用し，実験環境を工夫して精度を 向上させることとした.

\section{（2）検証方法}

構築したシステムを，より有効に $\mathrm{RC}$ はり部材の載荷 実験に適用するために，1) 標点寸法，2) 撮影画像の明る さ，3) 載荷時の照明環境，を検証した。 すなわち, 図一 に示すとおり，2つの標点を貼付したデジタル式マイク ロメータ (最小表示量 : $1.0 \times 10^{-3} \mathrm{~mm}$ )を使用して, 0.01 $\mathrm{mm}$ ごとに $0.5 \mathrm{~mm}$ まで画像解析結果とマイクロメータに よる計測值を比較し，その差分を絶対誤差とした.

実験では，カメラキャリブレーションを行うため必 要となる木板を, 標点と同一平面に設置している. カメ ラは，標点から約 $700 \mathrm{~mm}$ 離れた位置に設置しており， 理論的空間分解能が後に示す $\mathrm{RC}$ 載荷実験と同様の約 $0.10 \mathrm{~mm}$ / 画素に相当するように, 焦点距離を調節した. また，載荷時の照明環境を再現するために，検証は， $\mathrm{RC}$ 部材載荷試験機近辺で実施した.

\section{（3）標点の寸法}

同一の画素数を有する画像上では，標点寸法が大き くなるにつれて, 画像処理により標点のエッジ検出の精 度が向上する，一方で，ひび割れとの交差により標点が 剥離する危険性が高まる. 格子法を用いた本研究では, 標点が 1 つでも欠けると有限要素モデルを構築できなく
なり，リアルタイム計測が実施困難になる．節点間隔を 増加させて対処することも考えられるが，その場合，変 位計測点が減少するため, ひずみ分布を高い解像度で可 視化することが困難になる.

そこで，直径が $3 \mathrm{~mm} ， 5 \mathrm{~mm} ， 9 \mathrm{~mm}$ である 3 種類の円 形標点を用意して, 画像解析結果の精度を検証した。

図-7(a)に，マイクロメータの計測值に対する絶対誤差 を， $0.005 \mathrm{~mm}$ ごとの度数分布として示す．また，凡例に は，絶対誤差の平均值を併せて示している．検証の結果， $3 \mathrm{~mm}$ の標点を用いた結果が示す絶対誤差は，0.02 mm以 上を示す割合が高く, 平均值も高い. 一方，直径 $5 \mathrm{~mm}$ および $9 \mathrm{~mm}$ を使用した検証では顕著な差が確認できな かった．したがって画像解析には，直径 $5 \mathrm{~mm}$ または 9 mm の標点を使用することが望ましいと考えられる. し かし，前述したひび割れ通過による標点剥離回避を考慮 に入れて, 本研究では直径 $5 \mathrm{~mm}$ の標点を使用すること とした.

\section{(4) 撮影画像の光量}

撮影時に適切な光量を $\mathrm{CCD}$ に取り入れた明るい撮影 画像ほど，標点と背景を明確に識別できるので画像解析 の精度も向上すると考えられる ${ }^{14)}$. そこで，デジタルカ メラの ISO 感度を 400，800，1600 として感光度を変化さ せた検証を行った。

図-7(b) に，検証結果を示す. 絶対誤差の平均值を比 較すると, ISO 感度の増加とともに平均值は減少してお り, 光量の多い明るい画像ほど, 画像解析の精度が向上 することを確認した．また，ISO 感度を高めることによ る画像中のノイズの増加 ${ }^{17}$ は， 2 章で示した画像の平滑 化処理によって十分除去できていると考えられる. 複数 保有するデジタルカメラの性能に応じて, ISO 感度を 800 あるいは 1600 として実験を行うこととした.

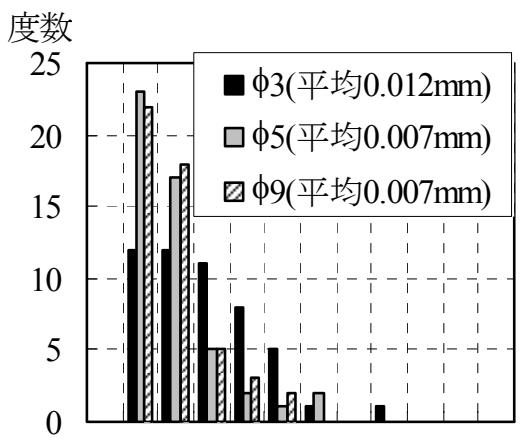

$\begin{array}{llllll}0 & 0.01 & 0.02 & 0.03 & 0.04 & 0.05\end{array}$ 絶対誤差(mm)

（a）標点の寸法(ISO640，工場照明)

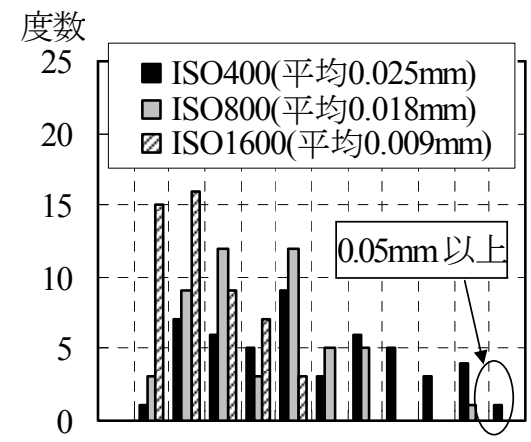

$\begin{array}{llllll}0 & 0.01 & 0.02 & 0.03 & 0.04 & 0.05\end{array}$ 絶対誤差 $(\mathrm{mm})$

（b） ISO感度（ $\phi=5 \mathrm{~mm}$ ，工場照明 $)$

図-7 絶対誤差の頻度分布

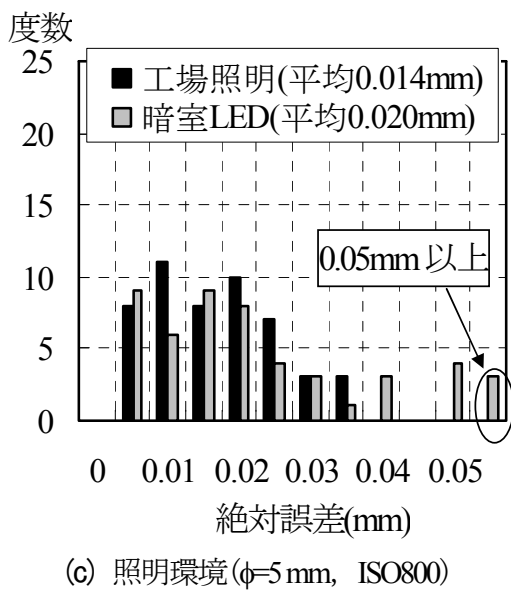

（c）照明環境 $(\phi=5 \mathrm{~mm} ， I S O 800)$ 


\section{（5）載荷時の照明環境}

載荷時の照明環境が，画像解析の結果に及ぼす影響 を検討した. 一般の照明器具を使用すると, 明るさにち らつき(フリッカ)があるために，撮影ごとに取得される 光量を一定にすることができない．これに対しては，カ メラの露出時間を照明の明滅周期と一致させることで対 処できる可能性があるが，現実には困難である．そこで， $\mathrm{RC}$ はりの載荷実験を想定して, 実験棟の水銀灯 (工場照 明)，および広域な面を均一な明るさにするために光を 拡散させる拡散板を装着した白色 LED $(55.68 \mathrm{~W})$ を暗室 で使用した照明環境(暗室 LED)を再現し，検証した。

図-7(c)に，検討の対象とした照明環境を用いた撮影 画像および実験結果を示す，絶対誤差は，暗室 LED の 条件下では $0.04 \mathrm{~mm}$ 以上を示寸割合が高く, 平均值も高 い值を示した. 撮影画像の輝度むらを低減するという点 では LED 照明が望ましい。しかし，本研究では暗室内 で対象物全域を照射するほどの光量を，保有する LED 数では得られなかった. そのため画像が暗くなり, 標点 と背景を識別する精度が低下したものと推察される.

したがって，4 章以降の RC はりの載荷実験では, 暗 室を使用せず水銀灯および LED 照明を併用して, 試験 体に多角的に光を照射することとした. すなわち，撮影 画像の光量を十分に確保しつつ, LED 照明の併用によ り水銀灯のフリッカの影響を低減して, 輝度むらの少な い均一な照明環境を再現することに努めた.

\section{4. 載荷時のRCはり破壊形態評価}

\section{（1）載荷実験概要}

\section{a）試験体作製}

表-1 に，コンクリートの示方配合を示す. 早強ポル トランドセメントを使用し, 水セメント比は 0.60 とし た. 粗骨材最大寸法は $20 \mathrm{~mm}$, コンクリートの目標圧縮 強度は $30 \mathrm{~N} / \mathrm{mm}^{2}$ である。

図-8に試験体の概要図を，表-2 に試験体諸元を示寸. 試験体は, せん断スパン $(a)$ が $420 \mathrm{~mm}$, 有効高さ (d) が $158 \mathrm{~mm}$ および幅 $\left(b_{w}\right)$ が $150 \mathrm{~mm}$ である. したがって, せ 儿断スパン有効高さ比 ( $(a / d)$ は 2.66 である. 試験体の断

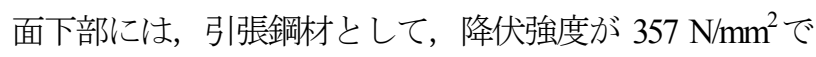
ある公称直径 $22 \mathrm{~mm}$ の異形鉄筋を 2 本配置した. 引張鋼 材比 $\left(p_{w}\right)$ は，3.27\%である．また，せん断補強鉄筋には， 公称直径 $6 \mathrm{~mm}$, 降伏強度 $\left(f_{m}\right)$ が $347 \mathrm{~N} / \mathrm{mm}^{2}$ である異形鉄 筋を使用した. 3 体の試験体作製の際は, 想定される破 壊形態を区別して，せん断補強鉄筋比 $\left(r_{w}\right)$ を工夫してい る. 寸なわち，耐力を試算した結果，想定される破壊形 態が斜め引張型破壊である $\mathrm{R}-03$, 曲げ引張型破壊であ る R-10, およびせん断耐力と曲げ耐力が同等である R-

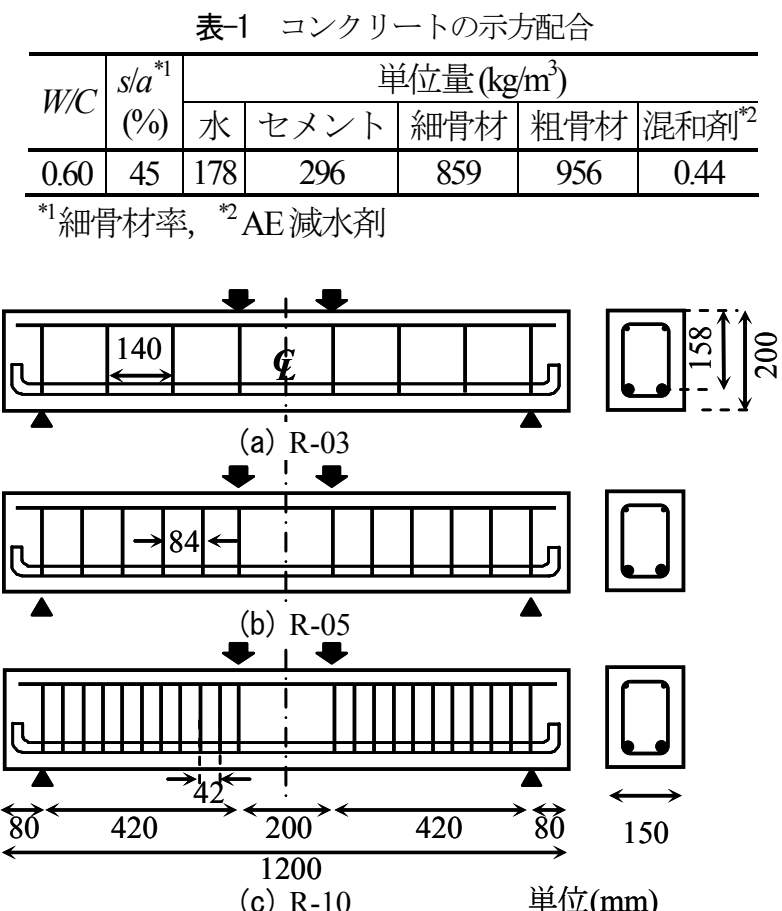

図-8 試験体概要図

表-2 試験体諸元

\begin{tabular}{|c|c|c|c|c|c|}
\hline \multirow[b]{2}{*}{ 試験体 } & \multirow{2}{*}{$\begin{array}{c}f_{c}^{\prime} \\
\left(\mathrm{N} / \mathrm{mm}^{2}\right)\end{array}$} & \multirow[b]{2}{*}{$\begin{array}{c}r_{w} \\
(\%)\end{array}$} & \multicolumn{2}{|c|}{ 耐力算定值 } & \multirow{2}{*}{$\begin{array}{c}\text { 想定される } \\
\text { 破壞形態 }\end{array}$} \\
\hline & & & $\begin{array}{c}\text { せん断 } \\
(\mathrm{kN})\end{array}$ & $\begin{array}{l}\text { 曲げ } \\
(\mathrm{kN})\end{array}$ & \\
\hline $\mathrm{R}-03$ & \multirow{3}{*}{30} & 0.30 & 132 & \multirow{3}{*}{160} & せん断 \\
\hline $\mathrm{R}-05$ & & 0.50 & 161 & & 曲げ/せん断 \\
\hline $\mathrm{R}-10$ & & 1.00 & 233 & & 曲げ \\
\hline
\end{tabular}

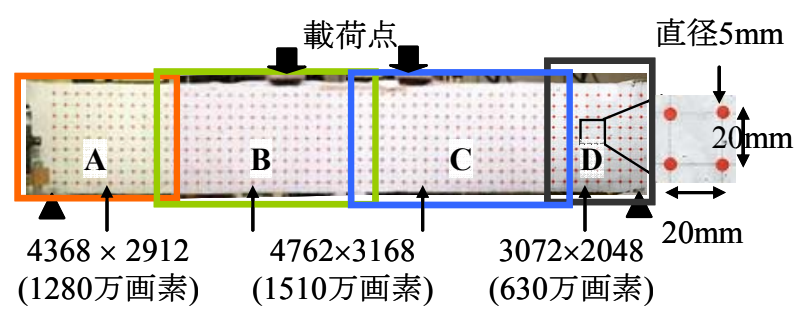

図-9 4台のデジタルカメラの撮影領域および解像度

05 である. せん断耐力 $V$ の照査には，式(6)に示寸修正 トラス理論を用い，せん断耐力のコンクリート貢献分 $V_{c}$ およびせん断補強鉄筋貢献分 $V_{s}$ には, 式(7)および式 (8)を用いた ${ }^{18)}$.

$$
V=V_{c}+V_{s}
$$

$$
\begin{gathered}
V_{c}=0.20 f_{c}^{\prime 1 / 3}\left(100 p_{w}\right)^{1 / 3}\left(\frac{1000}{d}\right)^{1 / 4}\left(0.75+\frac{1.4}{a / d}\right) b_{w} d(7) \\
V_{s}=A_{w} f_{w y} \frac{z}{s}
\end{gathered}
$$




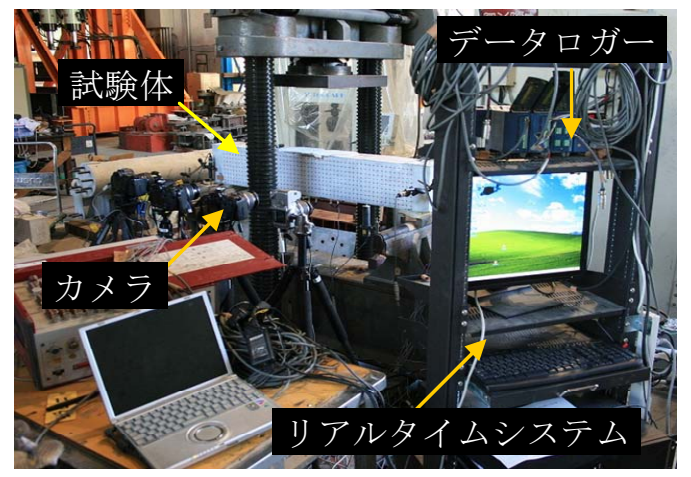

(a)リアルタイム画像解析システムおよびコンピュータ

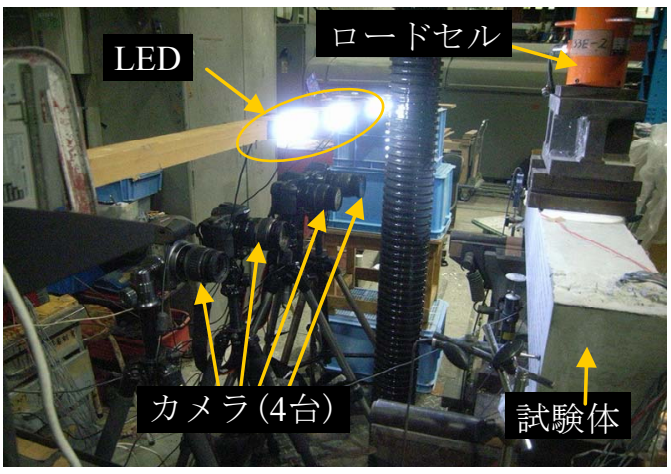

(b) カメラおよびLED照明

図-10 各種試験機器設置状況

ここで， $A_{w}$ : せん断補強鉄筋 1 組の断面積 $\left(\mathrm{mm}^{2}\right)$, $z=7 d / 8(\mathrm{~mm}), s$ : スターラップの軸方向ピッチ $(\mathrm{mm})$, および $f_{c}^{\prime}$ : コンクリートの圧縮強度 $\left(\mathrm{N} / \mathrm{mm}^{2}\right)$, である.

\section{b）載荷概要および測定項目}

RCはりの載荷は，静的4点曲げ載荷を行った．支点に は，減摩パッドを扦入し，支点の水平方向の拘束を除去 している.

計測項目は，荷重，支間中央と支点の鉛直方向変 位，軸方向鉄筋の支間中央のひずみ，せん断補強鉄筋の 試験体高さ中央位置のひずみ，コンクリートの支間中央 の圧縮縁ひずみ，および等モーメント区間に標点間隔が 100 mmである 幅を計測した．また，試験体の支点上方に変位計を配置 することで，面外方向の試験体の回転を監視した.

\section{(2) 画像計測概要}

図-2（a)に示したとおり，試験体表面を白色で塗装し， 支点間の $160 \times 1040 \mathrm{~mm}$ の領域に，直径 $5 \mathrm{~mm}$ の円形状赤 色標点を接着剤を用いて $20 \mathrm{~mm}$ 間隔で格子状に配置し た. なお，この計測対象領域を現状の汎用デジタル一眼 レフカメラ (1510 万画素) で捉えると，十分な空間分解能 が得られず，したがって RC はりの破壊形態の分析が困 難であると考えた，そこで実験では，市販の4台のデジ タル一眼レフカメラを使用して, 試験体片側側面の支間 全域を撮影した．図-9に，使用したデジタルカメラの 解像度およひ撮影領域を示寸，撮影範囲は，焦点距離お よび撮像素子寸法より理論的に算出して, 各撮影画像の 1 画素が $0.075 \sim 0.09 \mathrm{~mm}$ に相当するように設定した. こ の精度は，コンクリートの弾性ひずタに関する情報とし ては信頼性が低いが，目視では判別しにくいひび割れの 有無を同定する上では十分なものである. すなわちこの 設定は，曲げあるいは斜めひび割れの進展・開口が，本 研究の試験体の部材としての機能低下に支配的に作用寸 ると考えられたことに由来している，それぞれのカメラ の設定值 (シャッター速度, $\mathrm{F}$ 值, 測光方法)は, 実験ご
表-3 載荷実験結果

\begin{tabular}{c|c|c|c|c|c}
\hline 試験体 & $\begin{array}{c}f_{c}^{\prime} \\
\left(\mathrm{N} / \mathrm{mm}^{2}\right)\end{array}$ & $\begin{array}{c}P_{m a x} \\
(\mathrm{kN})\end{array}$ & 破懐モードー & \multicolumn{2}{|c}{$\begin{array}{c}\text { 算定值 } \\
(\mathrm{kN})\end{array}$} \\
\hline $\mathrm{R}-03$ & 34.4 & 171 & 斜め引張 & 136 & $\begin{array}{c}\text { 曲げ } \\
(\mathrm{kN})\end{array}$ \\
\hline $\mathrm{R}-05$ & 34.4 & 174 & 斜め引張 & 165 & 165 \\
\hline $\mathrm{R}-10$ & 32.4 & 177 & 曲げ引張 & 235 & 163 \\
\hline
\end{tabular}

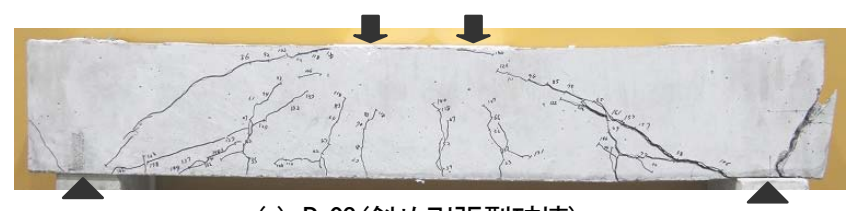

(a) R-03(斜め引張型破壊)

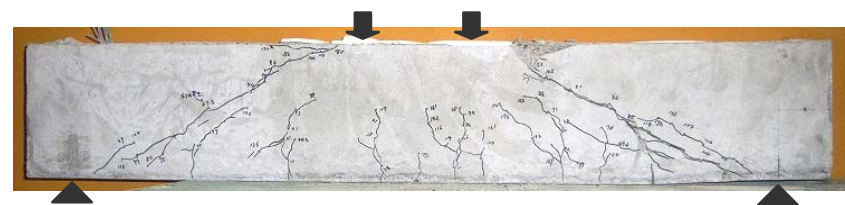

(b) R-05(斜め引張型破壊)

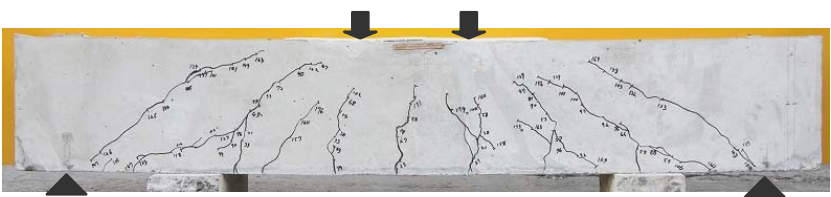

(c) R-10 (曲げ引張型破壊)

図-11 試験体の破壊性状(試験終了後, 画像解析対象面裏側を 示寸. )

荷重 $(\mathrm{kN})$

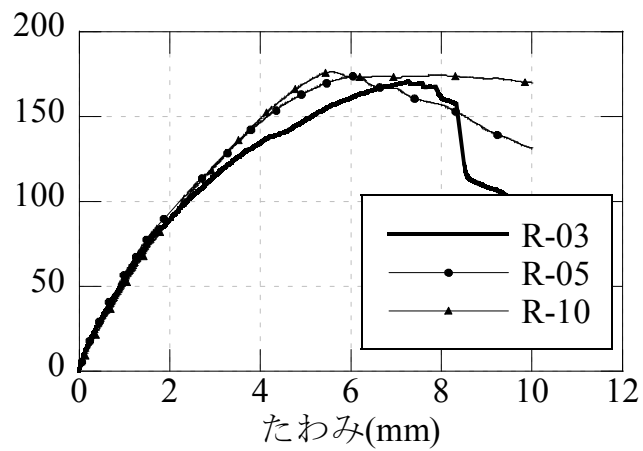

図-12 荷重一たわみ関係 


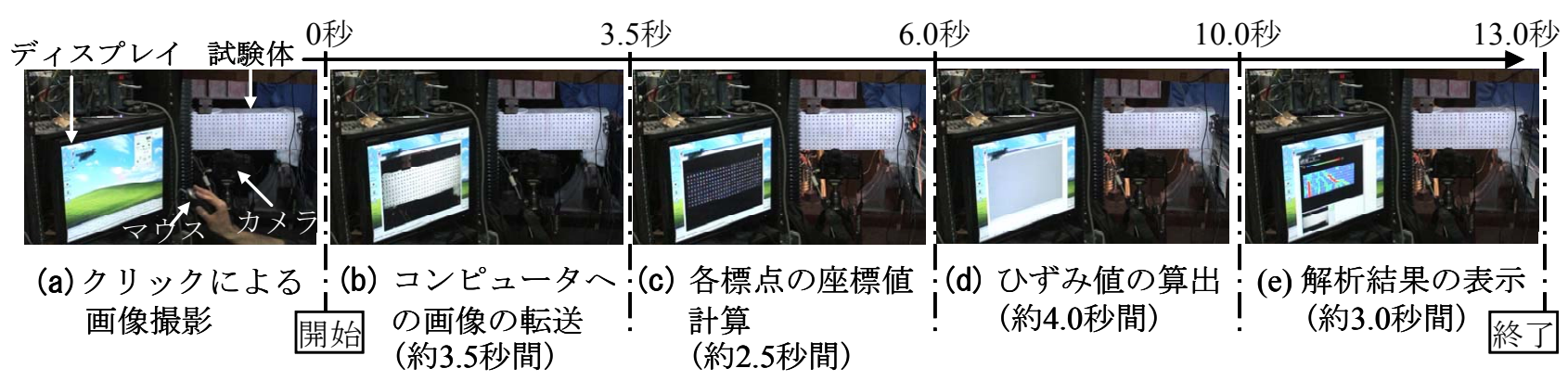

図-13 載荷試験における本システムの稼働状況および画像解析に要する時間

とに臨機応変に設定し，載荷中には固定した。

図-10 に，載荷中における各計測機器設置状況を示寸. 振動による画像悪化を懸念して, カメラを実験室床に三 脚で固定して, リモコンでシャッターを押した. 載荷時 の照明には，3 章の検討結果を踏まえ LED ライトを試 験体より約 $800 \mathrm{~mm}$ 離れた位置に設置することで, 試験 体を均一に照射し, フリッカの影響を低減した (図10 (b)). カメラキャリブレーションを実施した後, 載荷 を開始した. 載荷中は, 荷重が約 $5 \mathrm{kN}$ 変化するごとに 4 台のカメラで同時に撮影寸ることで，試験体の時系列画 像を取得した。

\section{（3）載荷実験結果}

表-3 に，RC はりの載荷実験結果をまとめる. 載荷実 験の結果， R-03 (斜め引張型破壊) および R-10 (曲げ引張 型破壊) は，予想された破壊形態を示した。一方，耐力 の算定では曲げ耐力とせん断耐力がほぼ同等であった R-05では, 最終的に斜め引張型破壊を示した.

図-11 に試験体の画像解析を実施した面の裏側の破壊 性状(実験終了後)を, 図-12 に試験体の荷重一たわみ関 係を示す，いずれも，せん断補強鉄筋比に依存した変化 がよく現れている.すなわち, 目視観察の結果, R-03 では, 荷重 $(P)$ が $30 \mathrm{kN}$ 程度で曲げひび割れが支間中央 部に発生し, $P=65 \mathrm{kN}$ では図-11 (a) 中の左側スパン中央 に斜めひび割れが発生した。 その後斜めひび割れは, 荷 重の増加とともに拡幅・進展し, スターラップが降伏し た後 $P=P_{\text {max }}$ に達した. 荷重がピークに達した以降のポ ストピーク域では, 載荷点外側のコンクリートの剥離, および支点外側のひび割れが，載荷試験終了時までに観 察されている．軸方向鉄筋は，降伏しなかった。

R-05 は，R-03 とほぼ同様のひび割れ性状を示した. すなわち, $P=30 \mathrm{kN}$ 程度で曲げひび割れが発生し, 約 $67 \mathrm{kN}$ で斜めひび割れが発生した. その後, 斜めひび割 れが進展するとともにスターラップが降伏ひずみに達し て, $P=P_{\text {max }}$ に達した. この時, 軸方向鉄筋は降伏しな かったが, ポストピーク域では, 載荷点外側のはり上縁 のコンクリートが剥離した.

一方，R-10 では， $P=P_{m a x}$ に達するまでにせん断スパ
ンに発生した斜めひび割れよりも，支間中央の曲げひび 割れが顕著に拡幅して，軸方向鉄筋が降伏ひずみを示し た．ポストピーク域の荷重一たわみ関係をみると， R-03 は急峻な軟化曲線が観察できたが，R-10 は，荷重がほ ぼ一定でたわみのみが増加する曲げ引張破壊型特有の現 象が確認できた. 最終的に載荷点間の圧縮縁のコンクリ ートが剥離したことを確認した後, 載荷を終了した.

\section{（4）画像解析システムの稼動状況および精度の検証}

図-13 に, 画像撮影後, 構築したシステムが解析結果 を表示するまでに要する時間を示す，画像解析は，標点 数 243 個を配置した $520 \times 200 \mathrm{~mm}$ (図-9 中のC)の領域を 対象としている. なお，使用したパソコンの性能は,

$2.13 \mathrm{GHz}, 2.00 \mathrm{GBRAM}$ である.

載荷中，パソコン上のクリックによりカメラのシャ ッターを押した. その後, 約 3.5 秒後に撮影画像がコン ピュータに転送され, 標点の座標位置を得るための画像 処理を約 2.5 秒で行った. その後, 算出した座標位置を 用いて，最大主ひずみを算出しコンター図で表示するま での作業が約 7.0 秒間であった. 寸なわち，撮影から約 13.0 秒後には， RC はりに発生している最大主ひずみの 分布がコンター図により可視化できたことになる．本実 験の載荷速度は約 $4 \mathrm{kN} /$ 分であったが，載荷を中断する ことなく, 載荷中に試験体に発生しているひずみの分布 を，十数秒で可視化することができた.

図-14(a)に，試験体の下縁付近に $20 \mathrm{~mm}$ ごとに配置し た標点間の水平方向の変位を示寸，なお，横軸は支間中 央からの距離を示しており, 図中の写真と一致している. 目視では, 荷重 $(P)=20 \mathrm{kN}$ および $25 \mathrm{kN}$ でひび割れを確 認できたが，画像解析の結果は，ほぼ同時にそれぞれの 位置の要素で変位が約 $0.03 \mathrm{~mm}$ および約 $0.05 \mathrm{~mm}$ に急増 している. また, 図-14(b)に, 荷重の増加に伴う画像解 析およびれゲージで計測した変位の変化を比較する。両 手法の計測長は, 同一の $100 \mathrm{~mm}$ である. 画像解析で得

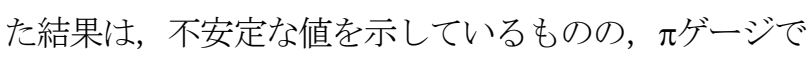
得た值と比較すればほぼ同様の傾向が得られており，本 システムで変位の変化を捉えることができた.

また，図-15に，画像解析および変位計から得た荷重 


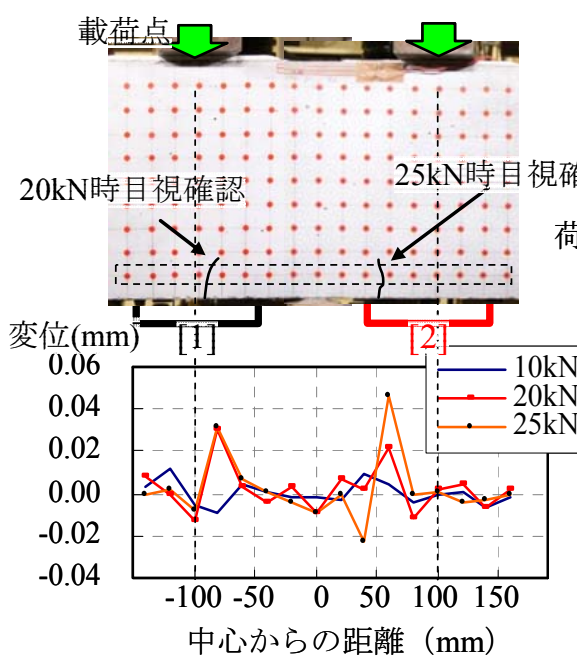

(a) 下縁の水平方向変位分布

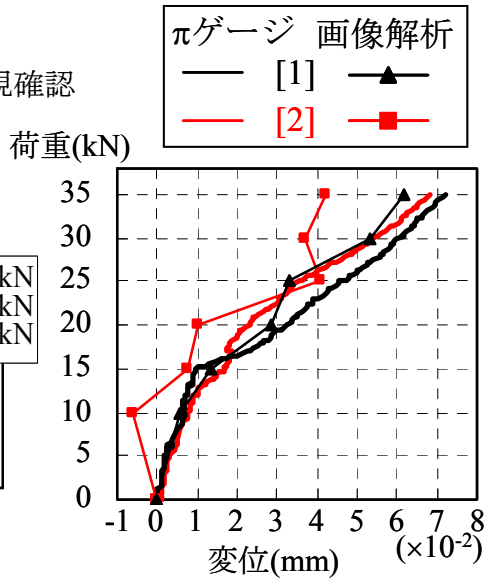

(b) $\pi$ ゲージの計測值

図-14 画像解析およびてゲージにより計測した断面下縁の変位の比較(R-03)

荷重 $(\mathrm{kN})$

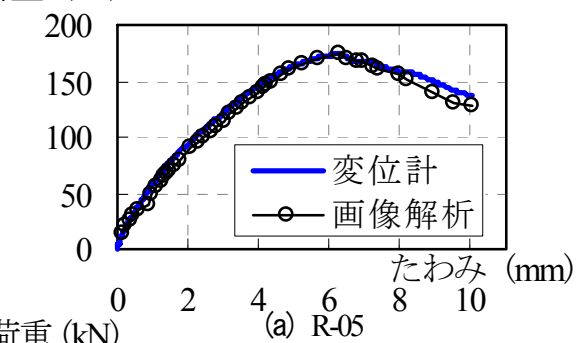

荷重 $(\mathrm{kN}) \quad$ (a) $\mathrm{R}-05$

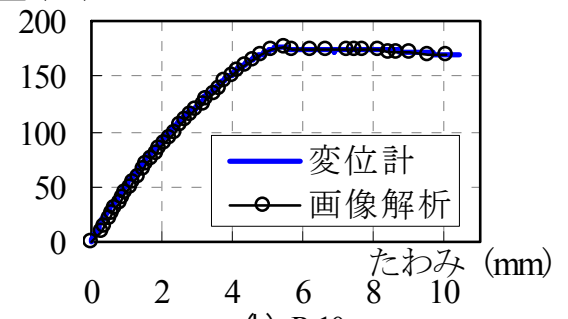

(b) R-10

図-15 荷重一たわみ関係の比較
一たわみ関係を示す．画像解析では，支間中央と支点付 近に設置した標点の垂直変位の差分として算出したが, 画像解析の計測值は，変位計より得た荷重一たわみ関係 を終始再現できている．このことから，本実験における 画像解析は，十分な測定精度を有していると判断される.

\section{（5）画像解析システムによる最大主ひずみ分布の可視化}

本研究で用意した試験体では, 斜めひび割れが進 展・拡幅してスターラップが降伏しピークに達する斜め 引張型破壊 (R-03)と，曲げひび割れが進展・拡幅して軸 方向鉄筋が降伏しピークに達寸る曲げ引張型破壊 (R-10) に区別される，そこで本論文では，これらの現象を念頭 におき，画像解析を通して得た最大主ひずみの分布に着 目して，曲げおよび斜めひび割れの進展・拡幅を把握す ることで，破壊形式を区別することを試みた.

図-16〜18 に，載荷中に行った画像解析を通して得た 最大主ひずみの分布をコンター図で表す，図中の黒い実 線は, 撮影画像より観察したひび割れを示しており, 図 は 4台使用したカメラごとに算出して得たコンター図を 統合して示している. なお, 各図とも (a)〜 (e) は各荷重 における全ひずみを，(f) (g) は荷重増加に伴うひずみ変 化を示している. また， RC はりの破壊要因を把握する うえでピーク時のひび割れ状況と関連がある， $P=P_{m a x}$ 時 のひずみ分布を明示するために, コンター図は 1 要素を $30 \times 30$ 個に分割して，0以下を青， 0.02 以上を赤で示して おり，その間を1024色に分割して着色している ${ }^{11)}$.

\section{a) R-03 (斜め引張型破壊)}

図-16に，載荷に伴い R-03に発生した最大主ひずみの 経時変化を示す.

荷重 $(P)$ が $70 \mathrm{kN}$ では(図-16(a))，0.005〜0.01 の高ひず み領域が曲げひび割れおよび左側スパンの斜めひび割れ
に沿って形成されている，荷重一たわみ関係では， $P=$ $88 \mathrm{kN}$ で勾配が変化したが, コンター図は $P=90 \mathrm{kN}$ まで に，左側スパンの斜めひび割れに沿って高ひずみ領域が 上縁に拡大しており (図-16(b))，この斜めひび割れが進 展および拡幅した結果であることが推察できる.さらに， 右側スパンでも，斜めひび割れ発生がひずみ集中域とし て確認できる.

$P=120 \mathrm{kN}$ までには, 左側スパンの斜めひび割れの拡 幅，および右側スパンの斜めひび割れ進展が，ひずみ分 布(図-16(c)) より推測できる. $P=120 \mathrm{kN}, 150 \mathrm{kN}$ (図16 (c)，(d))では，両側せん断スパンの斜めひび割れ位 置に沿って，0.02 以上のひずみの集中領域が拡大してい ることが確認された. 図-16(f) (g) は， $P=90 \mathrm{kN}$ に対す るそれぞれの増分ひずみを示すが，曲げひび割れよりも 斜めひび割れ位置でひずみが増加していることを明確に 示していることから，斜めひび割れの拡幅が示唆された.

$P=171 \mathrm{kN}$ (図-16(e))では，載荷点間の曲げひび割れ発 生位置に相当するひずみ集中領域の大きさおよび絶対值 は，図-16(d) と比べても顕著な変化が見られない。むし ろ, 斜めひび割れに沿った 0.02 以上の值を示す高ひずみ 領域が拡大したことで最大值に達したことが推測でき る.なお，右側スパンの斜めひび割れに沿った高ひずみ 集中領域は拡大しているが，支点には到達していない. 一方，左側スパンのひずみ集中領域は， $P=90 \mathrm{kN}$ 以降, 載荷点から支点へと連続して高ひずみ領域が拡大してお り, 試験体の上下縁を貫通して進展した左側せん断スパ ンの斜めひび割れが拡幅および進展して, 試験体の破壊 に支配的に作用したことが推測できる.このことは，ポ ストピーク域において, 左側スパンの高ひずみ領域がさ らに拡大して，変形が左側スパンに集中したことからも 判断できる. 
荷重 $(\mathrm{kN})$
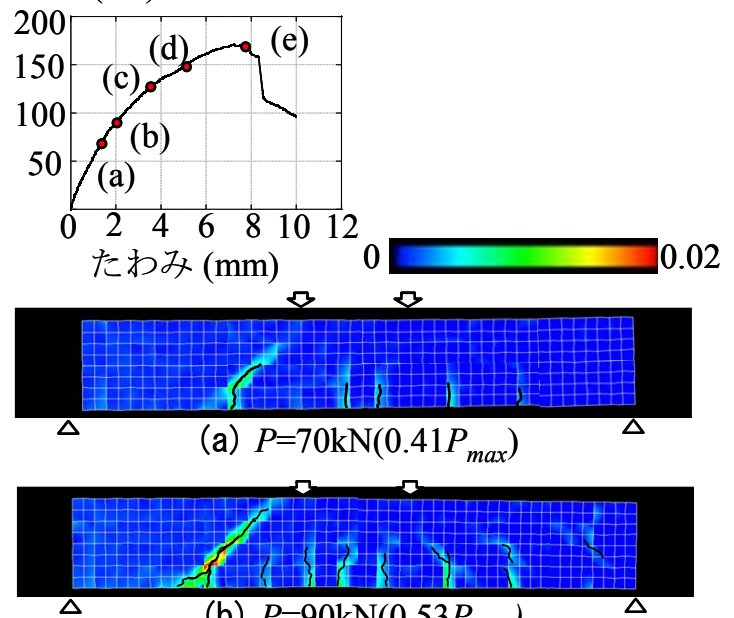

(b) $P=90 \mathrm{kN}\left(0.53 P_{\max }\right)$

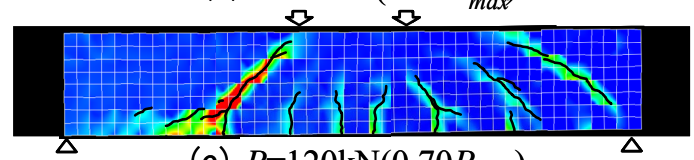

(c) $P=120 \mathrm{kN}\left(0.70 P_{\max }\right)$

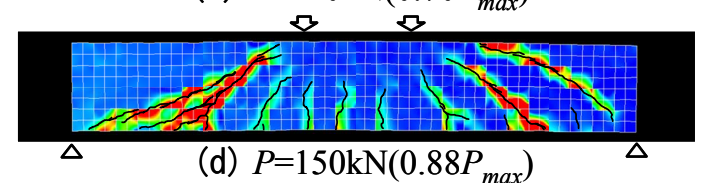

(d) $P=150 \mathrm{kN}\left(0.88 P_{\max }\right)$

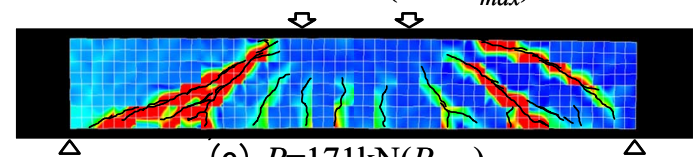

(e) $P=171 \mathrm{kN}\left(P_{\max }\right)$
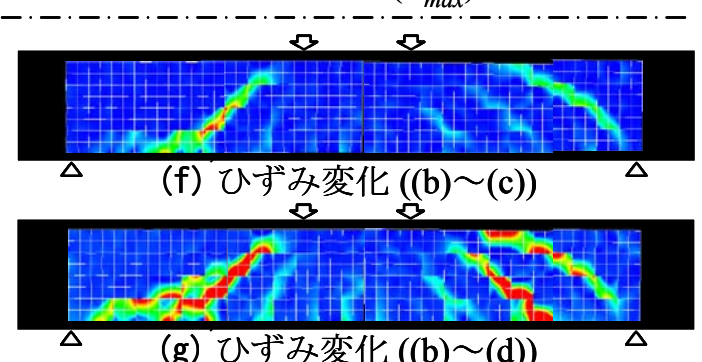

（g）ひずみ変化 ((b)〜 (d))

図-16Ｒ-03における最大主ひずみ分布の経時変化

なおコンター図には，載荷が進むにつれて，左側支 点上部にムラがみられた。 これは, 支点の水平方向の摩 擦を除去したことで，R-03は，実験終了までに面外方向 に最大約 $1.5 \mathrm{~mm}$ 回転したために焦点距離が変化したこと による計測誤差であると考える，なお，R-10およびR-05 の水平変位は, 最大 $0.07 \mathrm{~mm}$ であり, 結果には大きく影 響を及ぼさなかった。

b) R-10 (曲げ引張破壊)

図-17に，載荷に伴い R-10に発生した最大主ひずみの 経時変化を示す.

$P=95 \mathrm{kN}$ 時(図-17(b))では, 最大主ひずみが 0.01 程度 を示すひずみ集中域がはり下縁に確認でき，観察した曲 げひび割れ位置とも良く一致している. さらに $P=160$ $\mathrm{kN}$ 時(図-17(c))では，R-03 の図-16(d) と比較して，R-10 の両側せん断スパンに発生している斜めひび割れに沿っ
荷重 $(\mathrm{kN})$
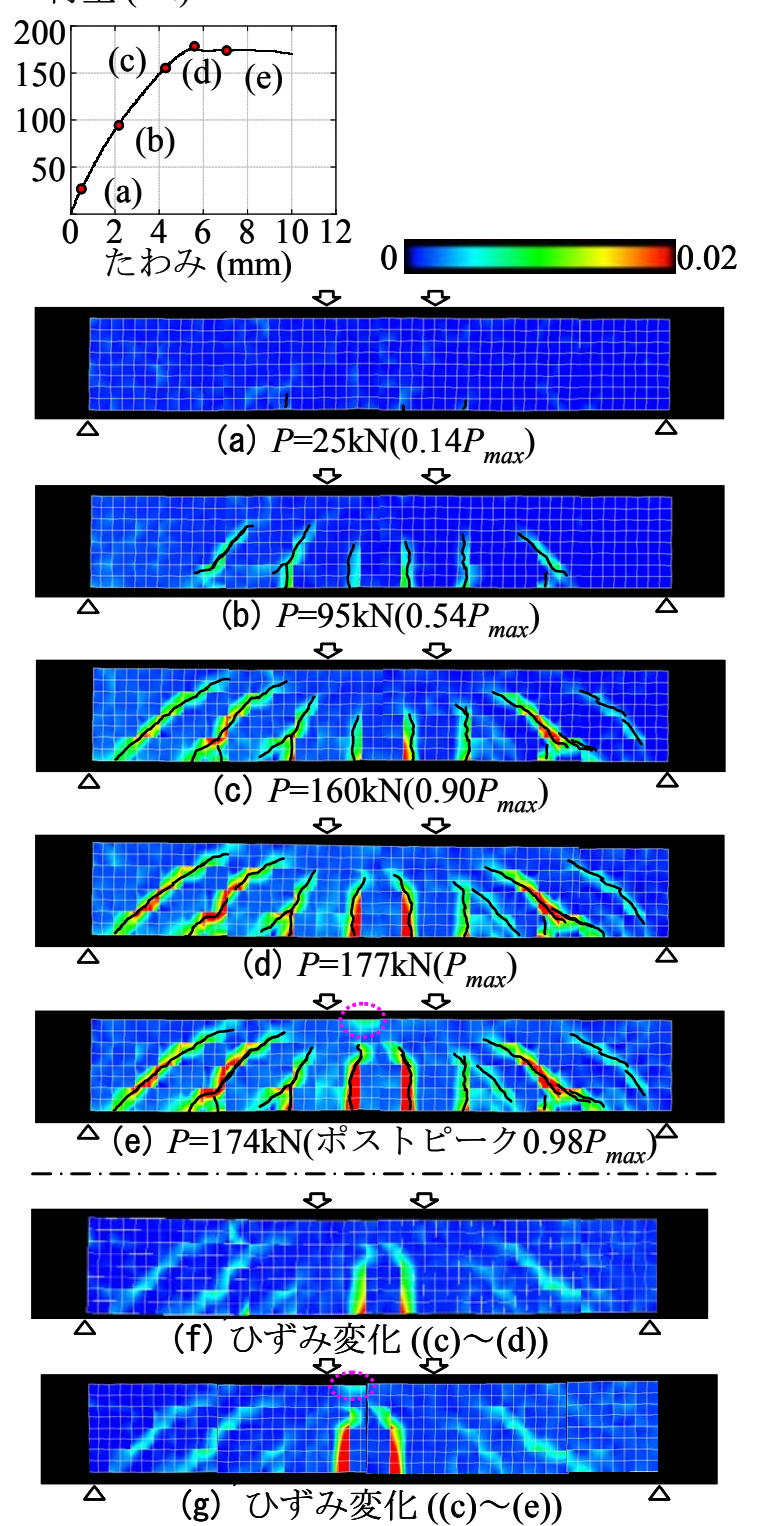

図-17 R-10における最大主ひずみ分布の経時変化

た高ひずみ領域は，顕著には拡大しておらず，図一 17 (f) (g)に示す, $P=160 \mathrm{kN}$ 以降のひずみ増分をみても 約 0.01 と小さいことがわかる. むしろ, 曲げひび割れ に沿ったひずみの集中領域が，試験体上縁に拡大してい る. 寸なわち, 曲げひび割れの進展・拡幅により試験体 はピークに達したことが推察される.

ポストピーク域(図-17(e))では, 図中の点線で囲む圧 縮縁に 0.01 程度のひずみ集中領域が判別でき, 圧縮縁 のひひ割れ発生を捉えている. 軸方向鉄筋降伏後に圧縮 縁のコンクリートにひび割れが発生したことを，目視観 察，軸方向鉄筋に貼付したゲージおよび画像解析の情報 から確認できた.

c) R-05 (曲げ耐力およびせん断耐力が同等)

図-18 に，R-05 の主引張ひずみの載荷に伴う経時変化 を示す. 
$P=95 \mathrm{kN}($ 図-18(a))では，はり下縁から約 0.01 以上の 最大主ひずみ集中領域が形成されており，曲げひび割れ の発生・進展を確認できる．また同時に，片側スパン中 央の試験体高さ中央位置に，ひずみ卓越領域が形成して おり，斜めひび割れの発生を確認できた。このとき， R03 の同一荷重時である図-16(b) と比較すると，R-05 の斜 めひび割れに沿ったひずみの值は約 0.01 と小さいこと から，せん断補強鉄筋比の違いによるひび割れ拡幅抑制 効果の差異が確認できる.

$P=125 \mathrm{kN} ， 155 \mathrm{kN}$ (図-18(b) (c))では，支間中央の曲 げひび割れ発生位置における高ひずみ領域が拡大し，は り下縁においては 0.02 を超えるひずみの発生が確認で きる.しかしそれ以上に，図-18(f)に示すとおり，両側 せん断スパンの斜めひび割れ位置に, $P=125 \mathrm{kN}\left(0.72 P_{\text {max }}\right)$ 以降，ひずみが顕著に増大しており，斜めひび割れが拡 幅し, 変位が集中して発生していることが，載荷中に推 察できた.

なお， R-05 および R-10 の荷重一たわみ関係を比較す ると(図-16)，P=150 kNに達するまでほぼ同様の曲線を 示した. しかし，斜めひび割れ位置における最大主ひず みの増分の点で, R-05 は, むしろ R-03 の示した特徴に 類似していた。 このことから，この荷重段階で R-05の 破壊形態は, 斜めひび割れが拡幅して終局にいたる斜め 引張型破壊であることが判別できた.

$P \fallingdotseq P_{m a x}$ (図-18(d))では，左側せん断スパンのひび割れ に沿って，0.02 を超える高ひず夕領域が顕著に拡大し， 載荷点付近から試験体下縁まで連続している。 この傾向 は，R-03 の図-16(d) の特徵に類似していたことからも， 左側スパンの斜めひび割れが試験体の破壊に支配的に作 用し， R-05 は斜め引張型破壞を示したことが改めて確 認できる。このことは，ポストピーク域(図-18(e)にお いて，左側スパンの斜めひび割れ位置にひずみがさらに 集中していたことからも判断できる.

\section{（6）リアルタイム画像解析システムを利用した RC 部材 の破壊形態の予測}

目視では判別できない主引張ひずみをリアルタイム 画像解析システムを利用して可視化することで， RC は り部材の曲げ引張型および斜め引張型破壊の差異を明確 にした，さらには，破壊形態が曲げ引張破壊か斜め引張 破壊か事前の計算では予想が困難であった $\mathrm{RC}$ 部材 (R05)でも, 載荷中に主引張ひずみを経時的に追跡するこ とで， RC はりの破壊に支配的に作用するひび割れを同 定できるとともに，最終的な破壊部位を載荷中に予測で きることを確認した.

本論文では，一本のひび割れが RC 部材の耐力低下に 支配的に作用寸る引張卓越型破壊を対象に，リアルタイ ム画像解析システムの妥当性を検証した。他にも破壊に
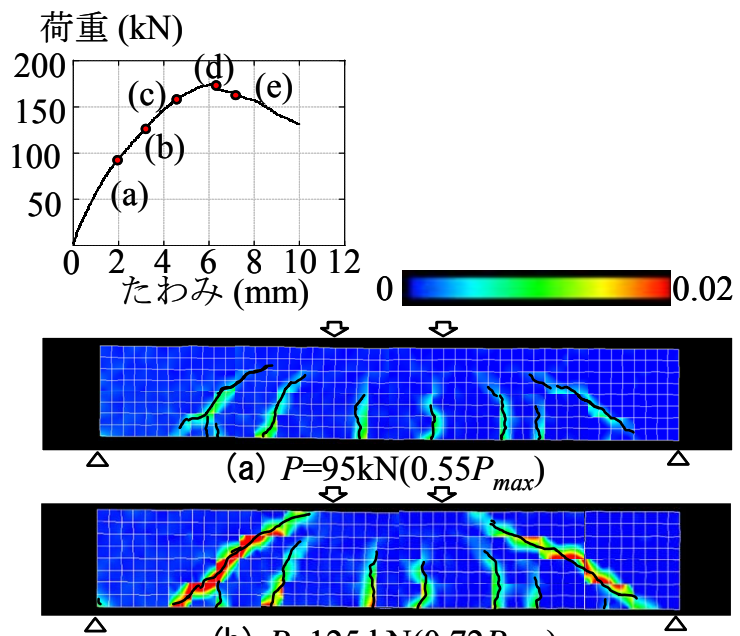

(b) $P=125 \mathrm{kN}\left(0.72 P_{\max }\right)$
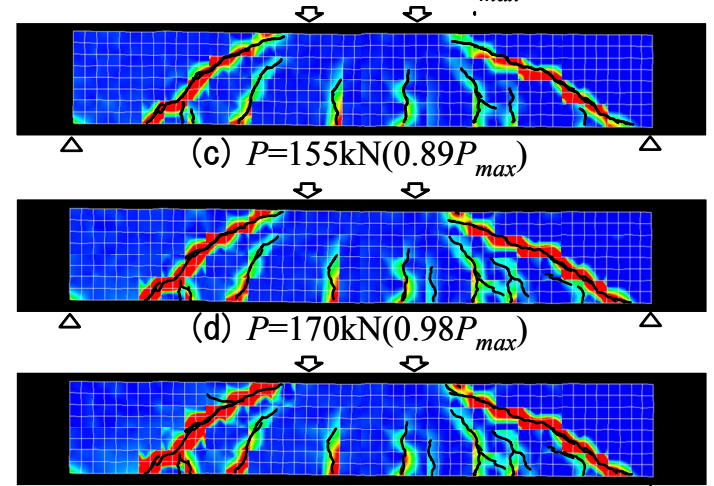

$\Delta$ (e) $P=160 \mathrm{kN}\left(\right.$ ポストピーク $\left.0.92 P_{\max }\right) \Delta$

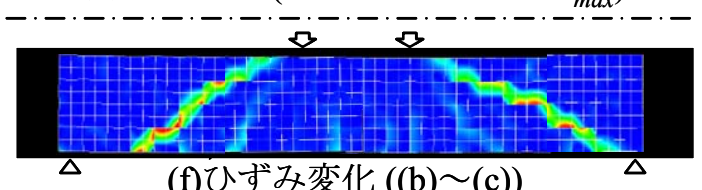

(f)ひずみ変化 ((b)〜 (c))

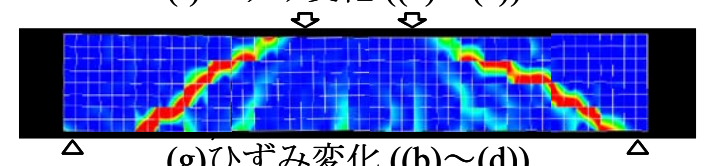

(g)ひずみ変化 ((b)〜 (d))

図-18Ｒ-05における最大主ひずみ分布の経時変化

伴う標点の剥離防止や，目的に応じた標点間隔および撮 影画像の空間分解能の工夫により，ひび割れが多く発生 するポストピーク域，あるいは最小主ひずみおよび主ひ ずみの方向なども検討に組み込むことができる，これは， $\mathrm{RC}$ ディープビーム ${ }^{19}$ およびプレストレストコンクリー 卜部材 ${ }^{20}$ など，最小主ひずみの分布が而何機構の解明に 重要となる $\mathrm{RC}$ 部材の実験にも，本システムを展開でき ることを示唆している. また, 複数のカメラを立体的に 配置することで，面外方向の変形など撮影対象とカメラ の焦点距離が変化する $\mathrm{RC}$ 部材の載荷実験にも追随でき る. すなわち，部材の諸元および支持条件に依存して複 雑に変化する $\mathrm{RC}$ 部材の破壊過程 ${ }^{21)}$ を，従来の計測手法 に加えて節点の変位と形状関数を用いて算出したひずみ 分布から載荷実験中に予測でき，より包括的な追跡を可 能にするという点で，本システムは RC 部材の破壊形態 の実験的な解明に貢献できると考えられるのである. 


\section{5. 結論}

1) 格子法によるリアルタイム画像解析システムを構築 した. 本システムは, 検查対象領域の抽出, 標点の 重心位置，マッチング，ひずみ算出，およびコンタ 一図による結果の表示という一連の作業を自動化し たものである. RC はり部材に適用した結果, 約十数 秒で画像解析を実施できることを確認した。

2) RC 部材の画像解析を実施するうえで, 試験体表面に 配置する標点の直径，ISO 感度および照明環境を，実 験環境に応じて最適化した。

3) 最大主ひずみ分布におけるひずみの局所化領域は, RC はりに発生したひび割れ位置と一致したことから， リアルタイム画像解析システムは, RC はり部材にお けるひび割れの発生および進展状況を再現できるこ とを確認した。

4) リアルタイム画像解析を利用して，せん断補強鉄筋 比に依存した RCはり部材の曲げ弓張型および斜め引 張型破壞の差異を，従来法による計測結果に加えて ひび割れ発生位置，進展および拡幅に着目して明確 にした。 その結果，破壊形態が曲げ破壊かせん断破 壊か事前の計算では予想が困難であった本研究の $\mathrm{RC}$ はり部材であっても, 載荷中に最大主ひずみ増分量 を経時的に追跡することで， RC はり部材の破壊に支 配的に作用するひび割れを同定でき，終局の破壊形 態を載荷中に予測できることを確認した.

なお，本研究の一部は，科学研究費補助金(基盤研究 (A)，課題番号19206050)によって実施した.

\section{参考文献}

1) 秋本圭一, 服部 進, 大西有三, 三浦 悟 : 画像計測法の卜 ンネル内空形状計測への応用, 土木学会論文集, No.687/III-56, pp.289-301, 2001.9.

2) 内野正和，小金丸正明，山口哲也，米山 聡 : デジタル画 像相関法によるひずみ計測(1)(デジタル画像相関法の高精 度化)，日本機械学会 2004 年度年次大会論文集(1)，No.041， pp.293-294, 2004.9.

3）矢川元基，松浦真一，安藤良夫：点認識画像処理を用い た非接触ひずみ解析法，日本機械学会論文集(A 編)，第 49 巻, 447号, pp.1435-1443, 1983.11 .

4) 浜岡広, 松田浩, 山下努, 中島朋史 : 光学的全視野計測 法による RCはりのひび割れ発生・進展の可視化，コンク リート工学年次論文集，Vol.28，No.2，pp.781-786，2006.7.

5) 出水享, 松田浩, 中島朋史, 浜岡広 : 非接触全視野計測 によるコンクリート材料試験，コンクリート工学年次論 文集，Vol.28，No.1，pp.473-478，2006.7.

6) 佐川康貴，尾上幸造，内野正和，松下博通：一軸圧縮力
を受けるモルタル供試体のひずみ計測へのデジタル画像 相関法の適用性に関する検討，実験力学，Vol.7，No.2, pp.20-26, 2007.2.

7) 野間康隆，渡辺 健，二羽 淳一郎：画像解析を用いた高強 度コンクリートの圧縮破壊進展機構，コンクリート工学 年次論文集，Vol.31，No.1，pp.523-528，2009.7.

8) 松尾豊史，酒井理哉，松村卓郎，金津 努 : 鉄筋腐食した $\mathrm{RC}$ はり部材のせん断而荷機構に関する研究, コンクリー 卜工学論文集, Vol.15, No.2, pp.69-77, 2004.5.

9）依田宏之, 相原啓二, 栗原哲彦, 吉川弘道 : RC 単純梁の せん断スパンにおける非線形挙動に関する実験的・解析 的研究，土木学会論文集 E, Vol.64, No.2, pp.285-297, 2008.4 .

10）松井義雄，権庸吉，上田尚史，中村光：せん断圧縮破壊 するはりの局所ひずみ分布と積分型非局所構成則の適用, コンクリート工学年次論文集，Vol.28，No.2，pp.775-780， 2006.7.

11）東広憲, 渡辺健, 三木朋広, 二羽淳一郎：画像解析を用 いた鉄筋コンクリートはりの破壞性状の予測，コンクリ 一ト工学年次論文集，Vol.30，№.3，pp.793-798，2008.7.

12）舘石和雄 : デジタルステレオビジョンによる広領域ひず み場計測システムの開発，土木学会論文集，No.693/VI-53, pp.87-94, 2001.12.

13) Kuchma, D., Sun, S. and Lee, H. H.: Collection and analysis of dense experimental test data, Fiffh International Conference on Urban Earthquake Engineering,pp.167-172, 2008.3.

14）豊田堅二 : デジタル一眼レフがわかる，技術評論社， 2008.8.

15) 株式会社リンクス 画像システム事業部：画像処理アルゴ リズムと実践アプリケーション，株式会社リンクス出版 事業部, 2008.6.

16) D. Hatt, G and Touzat, G (福田収一監訳) : 有限要素法全解, パ ーソナルメディア, 1990.9.

17) 神崎洋治, 西井美鷹: 体系的に学び直すデジタルカメラ の仕組み, 日経 BPソフトプレス, 2004.5.

18) 二羽淳一郎，山田一宇，横沢和夫，岡村甫 : せん断補 強鉄筋を用いない $\mathrm{RC}$ はりのせん断強度式の再評価，土木 学会論文集，No.372N-5，pp.167-176，1986.8.

19）幸左賢二，脇山知美，西岡 勉，小林 寛: せん断スパン比 に着目したディープビームの破壊形態に関する実験的検 討，土木学会論文集 E，Vol.62，No.4，pp.798-814，2006.11.

20) Sivaleepunth, C., Niwa, J., Bui, K. D., Tamura, S., and Hamada, Y.: Simplified Truss Model for Externally Prestressed Concrete Beams, Journal of Materials, Concrete Structures and Pavements (Doboku Gakkai Ronbunsyru E), Vol. 63, No. 4, pp. 562-574,2007.10.

21) 渡辺 健, 田所敏弥, 谷村幸裕, 黒川浩嗣 : 逆対称曲げが 作用したディープビームの破壊性状に関するせん断スパ ン比の影響, コンクリート工学年次論文集, Vol.29, №.3, 


\section{REAL-TIME IMAGE ANALYZING SYSTEM FOR LOADING TESTS OF STRUCTURAL CONCRETE}

\section{Ken WATANABE, Hironori HIGASHI, Tomohiro MIKI and Junichiro NIWA}

This research has developed a real-time image analyzing system for evaluating the strain generated on the surface of RC beams during the loading test. The influential parameters on the analyzed results were also examined. The developed system was applied to the four-point bending test of slender RC beams and the maximum principle strain generating on the surface of RC beams during the test was visualized. The visualized strain distribution was able to evaluate the strain concentration area, and predict the failure mode of RC beams before the load reached the maximum. 